\title{
Evaluation of pomological and biochemicalquality of Moroccan almond native genetic resources for conservation of biodiversity
}

\author{
Souhayla Kodad*, Reda Melhaoui, Nadia Houmy, Mohamed Addi, Hana Serghini-Caid, Ahmed Elamrani, \\ Malika Abid, and Aatika Mihamou
}

Laboratory of Agricultural Production Improvement, Biotechnology and Environment LAPABE, Faculty of Sciences, Mohammed Premier University, Oujda, Morocco

\begin{abstract}
The edible and tasty almond \{Prunus amygdalus [syn. P. dulcis (Mill.) D.A.Webb] kernel is not anymore the main reason for its production and uses, other properties related to its by-products, especially the sweet edible almond oil, which is mainly used as a salad dressing or as an ingredient in a highly appreciated Moroccan almond-based recipes. The studied almond populations are derived from seedling, the trees of these plantations are very heterogeneous in terms of vigor and flowering time and are facing a genetic bottleneck due to an attack by an insect 'bark beetle', as well as the introduction of new foreigner cultivars. Our preliminary study concerns the evaluation of fruits quality of locally commercializedalmond ecotypes, with a shelling rate ranging from $22.37 \%$ to $34.21 \%$ and it comparison with the introducedFrench cultivars couple Ferragnes/Ferraduel $(\mathrm{Fg} / \mathrm{Fd})$ grown in the same region, that presents higher commercial values but yet lowest nutritional traits compared to local populations.Since Beldi almonds showed higher total tochopherols content with avalue equal to $511.64 \mathrm{mg} / \mathrm{kg}$, while for $\mathrm{Fg} / \mathrm{Fd}$ cultivars it presents only $433.1 \mathrm{mg} / \mathrm{kg}$. Hence the interest of a detailed study to prove both the genetic variability of local Beldi almond populations for the conservation of biodiversity, and also the biochemical propertiesof almond oils and cakes lead to post-harvest recovery of these products by increasing it commercial value in favour of local farmers and cooperatives.
\end{abstract}

\section{Introduction}

Almond (Prunus dulcis) ), is one of the oldest domesticated fruit trees and it has been adapted to various microclimate in many countries over the globe[1]. It is also a major nut tree grown in the Mediterranean climate [2]. The traditional cultivation of almonds used open-pollinated seedlings [3] which, with self-incompatibility, produced very strong heterozygosity within this species [4].This great variability provided a useful genetic pool for almond germoplasm evolution allowing in each growing region a selection of well adapted almond cultivars [5].World almond production was 2.2 million tons in 2017, and only the United States provided $46 \%$ of the total production (FAOSTAT.2018). The production also involves many Mediterranean climate areas. The most important major growth areas in modern times are Spain, Italy, Morocco, Tunisia, Greece and Portugal[6]. Spain, Iran and Morocco are considered to account for $22 \%$ of the world's total production.

Morocco has seen through 'Plan Maroc Vert' a massive introduction of new varieties of almond trees with late blooming cultivars allowing them to escape late frosts and ensure better productionwith fruits of a high physical quality. The introduction of the new varieties has made local "Beldi" almond orchards less abandoned or replaced, causing genetic erosion and regression of the indigenous almond populations while they have demonstrated through decades their tolerance to drought and adaptation to poor soils in these fragile agroecological zones. Moreover, some physicochemical analysis of the local almonds fruits quality collected from different regions of Morocco has already revealed a high quality of these almonds[7], [8] suggesting other potential post-harvest uses such as marzipan production, almond meal and oil. This could increase the market value of these fruits and improve the income of local farmers. Thus, finding and characterizing the old genotypes for the conservation of biodiversity is of definite interest in the diversity of cultures within these almond groves. The results could also be useful for the management of almond germplasm and for the selection of the best parental genotypes for breeding programs.

*Corresponding author: souhaila.kodad@gmail.com 
More than half of the almond trees grown in Morocco originate from seedlings, mostly located in the north and in the south of the country. Great diversity in almond trees resulting from the variability of the environmental conditions and the climate changes has been shown in each production region. Numerous studies had been undertaken to evaluate genetic variability and quality of nuts within the Moroccan almond population using morphological and phonological characteristics [9], but there are minimal studies on the chemical composition of almonds, mainly concerning kernels, the edible part which have a very significant nutritional value. The knowledge of its chemical composition will allow the assessment of not only quality criteria but also consumption criteria due to the incidence of certain compositional parameters on the shelled almond's nutritional and health values [6]. It will be essential to characterize the local Beldi almond chosen for their performance and their productivity, according to their pomological characterization, in order to identify the genotypic richness, the relationship between the local populations and the introduced cultivars, and also to prove the genetic variability which can be exploited for the conservation of the biodiversity. Concurrently, the analysis of the organoleptic and nutritional properties of almond oils and cakes will lead to the postharvest development of these products in favor of pilot cooperatives. The search for distinctive characteristics, whatever the nutritional characteristics of Beldi almonds, according to production zones, will also make it possible to highlight the characteristics linked to the territory. Since, nowadays determining the authenticity and origin of food is a key issue in food quality control and management[10]. The main objective of this work is to assess pomologicaly characterized almonds of the Beldi ecotypes in Northeastern Morocc oby biochemical characterization of its oils and cakes in order to highlight the different components of the almond kernel and to emphasize its importance in considering almonds quality and to prospect its evaluation in breeding programs.

\section{$2 \quad$ Materiel and methods}

\subsection{Pomological characterization of almond nuts and kernels}

The different Beldi ecotypes batches (L1, L2, L3, L4, L5, and L6) considered in the present study have been bought in a local niche market in eastern Morocco from local fruit growers. The pomological characterization was carried out on fruits (almonds and kernels), according to the descriptor of the International Board for Plant Genetic Resources [11].The sphericity ( $\Psi$ ) of the nuts and grains was determined using equation (1) The geometric mean diameter $(\mathrm{Dg})$ is calculated according to equation (2)[12], and the volume of the nuts and grains (V) can be calculated using the following equation (3)[13]:

$$
\begin{aligned}
& \varphi=\sqrt{ }(3 \& L W T) \times 100 / L \\
& D g=\sqrt[3]{L} W T \\
& V=\left(\pi[D g]^{\wedge} 3\right) / 6
\end{aligned}
$$

\subsection{Biochemical analyses of almond oils}

The extraction of the oils was carried out at a cooperative of SIDI BOUHRIA in eastern morocco by using an oil screw press extractor KOMET model DD85G. The analyses were carried out one week after the extraction.

\subsubsection{Oil content}

Oil content was calculated using the weight of the bottle containing the oil minus the weight of the same empty bottle divided by the weight of the dry kernels of four studied Beldi ecotypes according totheir shelling rates, which are L1,L2,L4 and L5. All of the oil extractions were performed in triplicate.

\subsubsection{Acidity index}

Acidity ( $\mathrm{g} / 100 \mathrm{~g}$ oleic acid) was defined as the percentage of free fatty acids that are present in the oil resulting from the hydrolysis of triglycerides. To define the acidity index of almond oil the following protocol was applied. $5 \mathrm{~g}$ of almond oil (P) are dissolved in $50 \mathrm{ml}$ of absolute ethanol, to which 8 drops of phenolphthalein $(1 \%)$ are added. The free fatty acids are titrated with stirring with an alcoholic solution of potassium hydroxide at $0.1 \mathrm{~N}$ (the pink color of the phenolphthalein persists for at least 10 seconds).

The free acidity is calculated according to the following formula:

$\%$ of free acid $=(\mathrm{V}(\mathrm{NaOH}) \times \mathrm{N}(\mathrm{NaOH}) \times$ molar mass $\times 100) / \mathrm{P} \times 1000$

$\mathrm{V}$ : volume of titration $\mathrm{NaOH}$ in 1

$\mathrm{N}(\mathrm{NaOH})$ : normality of $\mathrm{NaOH}$

$\mathrm{P}$ : test sample 


\subsubsection{Peroxide index}

The peroxide index (PI) was used to estimate the content of hydroperoxides present in the oil (primary oil oxidation products). This index was determined by the so-called acetic acid and chloroform method corresponding to the AOCS Cd 8-53 standard. According to the following protocol:5g (P) of almond oil were dissolved in $30 \mathrm{ml}$ of a chloroform acetic acid mixture $(3: 2 \mathrm{v} / \mathrm{v})$ then $0.5 \mathrm{ml}$ of a saturated solution of potassium iodide were added to the mixed. Finally $30 \mathrm{ml}$ of distilled water are added after exactly one minute of stirring. This solution was then titrated with $0.01 \mathrm{~N}$ sodium thiosulfate using starch as a color indicator.

The peroxide value is expressed in milliequivalents peroxide per $1000 \mathrm{~g}$ of oil according to the following formula:

IP $($ meq O2 $/ \mathrm{Kg})=[(\mathrm{VE} \times \mathrm{M} \times 1000] / \mathrm{P}$

VE: volume of sodium thiosulfate for sample titration

P: test sample

\subsubsection{Colorimetric determination of phenolic contents}

Total phenolic contents were determined according to the Folin-Ciocalteu method by using caffeic acid as a standard, and by spectrophotometric absorbance measurement at $760 \mathrm{~nm}$. Folin Ciocalteu's reagent is a yellow acid consisting of a mixture of phosphotungstic acid (H3PW12O40) and phosphomolybdic acid (H3PMo12O40). It is reduced, during the oxidation of phenols, to a mixture of blue oxides of tungsten and molybdenum [5]. The coloring produced, whose maximum absorption at $760 \mathrm{~nm}$, is proportional to the quantity of polyphenols present in the almond oil extracts [5].

\subsubsection{Determination of total proteins}

The total protein determination consists in measuring the total nitrogen by the Kjeldahl method and in multiplying this nitrogen content by a conventional factor 6.25 [5]. The principle of this method consists of mineralization of a sample with sulfuric acid in the presence of a catalyst, alkalization of the reaction products, distillation of the released ammonia collected in a solution of boric acid, and titrated by sulfuric acid solution.

\subsection{Biochemical analyses of Beldi almond oil cakes}

\subsubsection{Dry matter content}

The container were placed in the oven at $103^{\circ} \mathrm{C}$ for 1 hour 30 minutes, then cooled in a desiccator away from ambient humidity before being tarred (P1) in a precision balance to 3 decimal places. Then $1 \mathrm{~g}(\mathrm{P} 2)$ of almond oiscakes wasweighed in each container. Then they were placed in the oven at $103^{\circ} \mathrm{C} \pm 2{ }^{\circ} \mathrm{C}$ until the weight is stable. They were then cooled in a desiccator away from ambient humidity and then weighed (P3).

Expression of the result:

The dry matter and the humidity are calculated according to the following formulas:

$\%$ Dry matter $(\mathrm{MS})=[100 \times(\mathrm{P} 3-\mathrm{P} 1)] / \mathrm{P} 2$

$\%$ Humidity rate $=100-\%(\mathrm{DM})$

\subsubsection{Total ash content}

The silica crucible previously weighed was placed in the muffle furnace at $550{ }^{\circ} \mathrm{C}$ overnight to ensure that the impurities are burned. Then, they have been cooled in a desiccator for 30 minutes before being tarred (P1) in a precision balance to 3 decimal places. About $1 \mathrm{~g}(\mathrm{P} 2)$ of the almond cakewas weighed into each crucible. These were placed in the muffle furnace at $550^{\circ} \mathrm{C}$ for 8 hours. The crucibles were then cooled in the desiccator away from ambient humidity and then weighed (P3). The expression of the total ash content results relative to the dry matter according to the following formula:

$\% \mathrm{Ash}=[100 \times(\mathrm{P} 3-\mathrm{P} 1)] / \mathrm{P} 2$

\subsubsection{Composition of major mineral elements}

The major elements analyzed in this study were potassium $(\mathrm{K})$, magnesium $(\mathrm{Mg})$, calcium $(\mathrm{Ca})$, and phosphorus (P). They were measured by different methods, UV-visible spectrophotometry at $700 \mathrm{~nm}$ for phosphorus, titration for magnesium $(\mathrm{Mg})$ and calcium $(\mathrm{Ca})$, while for potassium $(\mathrm{K})$, it was measured by a SHERWOOD model 360 flame photometer. The mineralization of samples was by measuring $2 \mathrm{~g}$ of almond cake in a Teflon container and 
placed in a muffle oven for 5 hours at $550^{\circ} \mathrm{C}$. Then $6 \mathrm{ml}$ of $65 \%$ nitric acid and $1 \mathrm{ml}$ of $35 \%$ hydrogen peroxide were added. The samples were subjected to mineralization in a high performance microwave digestion unit (MLS $1200 \mathrm{meg}$ ) using the following program: $250 \mathrm{~W}: 2 \mathrm{~min} ; 0 \mathrm{~W}: 2 \mathrm{~min} ; 250 \mathrm{~W}: 6 \mathrm{~min} ; 400 \mathrm{~W}: 5 \mathrm{~min} ; 600 \mathrm{~W}$ : $5 \mathrm{~min}$; ventilation: $10 \mathrm{~min}$. The program used is based on the manufacturer's recommendations for use (microwave, January, 1995). The rotor was then cooled for one hour.

\subsubsection{Crude cellulose determination}

The crude fiber analysis was performed using the FIWE fibre analyser (VELP SCIENTIFICA). With the $1 \mathrm{~g}$ of almond oil cake samples remaining inside the crucibles to avoid the loss of fibre due to the transfer according to AOAC, 1990[5].

\subsubsection{Determination of total sugars}

Total sugar was measured according to the Bertrand method, the principle of which is that the glucose partially reduces Fehling's liquor in excess the cuprous oxide formed (red precipitate) is dosed by manganimetry. A table gives the correspondence between the mass of copper and the mass of glucose. The reaction must take place hot and for three minutes from boiling to respect the correspondence of the tables. A quantity of glucose reacts with the excess copper (II) ions to form a brick-red precipitate. Excess copper (II) ions were eliminated. The precipitate reacts with an excess of iron (III) ions to dissolve it. Iron (II) ions were obtained, and dosed with a solution of potassium permanganate.

\subsection{Comparison between the Beldi ecotypes and Fg/Fd cultivars according to the major fatty acids and the tocopherol isomers grown in eastern Morocco}

\subsubsection{Tocopherols profile analysis}

According to the official method, AOCS 8-89 (AOCS 1989), tocopherols analyses were performed by using HPLC-FLD, (Agilent Technologies series 1200 system, Agilent Technologies). It was equipped by an automatic injector, on a Uptisphere $120 \mathrm{~A}^{\circ} \mathrm{NH} 2$ column $(150 \mathrm{~mm} * 3 \mathrm{~mm}, 3 \mu \mathrm{m})$ Interchim (Montluçon, France). $10 \mu \mathrm{L}$ was injected. The temperature was maintained at $30{ }^{\circ} \mathrm{C}$. The mobile phase was hexane/2-propanol $(99: 1, \mathrm{v} / \mathrm{v})$ with a flow rate of $1 \mathrm{~mL}$ min-1. The different tocopherol isoforms $(\alpha-, \beta$-, $\gamma$-and $\delta$-tocopherols) were evaluated using oil/hexane solution of both the studied Beldi ecotypes oils, and $\mathrm{Fg} / \mathrm{Fd}$ cultivars oils extracted by using the same screw press extractor. The obtained tocopherols from Sigma-Aldrich (Steinheim, Germany) were used as external standardization for the identification of tocopherols at $292 \mathrm{~nm}$. Tocopherol homologs were quantified by comparing each sample peak response to that of the corresponding standard.

\subsubsection{Fatty acid analysis}

The present analysis was also conducted for both Beldi almond ecotypes and Fg/Fd cultivars. The fatty acids were converted to fatty acid methyl esters before analysis by mixing a solution of $10 \mathrm{mg}$ of oil in $0.2 \mathrm{~mL}$ of hexane with $0.5 \mathrm{~mL}$ of another solution composed by $55 \mathrm{~mL}$ of dry methanol added to $20 \mathrm{~mL}$ of pentane and 25 $\mathrm{mL}$ of BF3 at $14 \%$ weight in methanol. The mixture was placed in a water bath for $90 \mathrm{~min}$ at $75^{\circ} \mathrm{C} .0 .6 \mathrm{~mL}$ of saturated $\mathrm{NaCl}$ and $0.2 \mathrm{~mL}$ of $10 \% \mathrm{H} 2 \mathrm{SO} 4(\mathrm{~V}: \mathrm{V})$ was added. HP 6890 series gas chromatography system was used for analyzing the fatty acid methyl esters. The system was equipped with an FID detector and a capillary column (Supelcowax: $30.0 \mathrm{~m} 9250 \mathrm{~mm} 90.25 \mathrm{~lm}$ ). The carrier gas was nitrogen. The temperatures were maintained at 150 and $250{ }^{\circ} \mathrm{C}$, for the injector and detector, respectively. While for the oven temperature, it was set at $210^{\circ} \mathrm{C}$. A comparison with the retention time of the respective ester standards was utilized for the identification of the individual fatty acid methyl esters.

\subsection{Statistical analysis}

The experimental design used in this study was completely randomized design. Each determination was performed in triplicate. All data were analyzed by Analysis of Variance (ANOVA), and Duncan's multiple range with SPSS software for Windows (SPSS.21, USA), the values of the various parameters were expressed as an average $(\bar{X})$. Only variables with a confidence level greater than $95 \%(P<0.05)$ were considered significant. 


\section{$3 \quad$ Results and discussion}

\subsection{Pomological characteristics of Beldi almond ecotypes}

The descriptive statistics of the Beldi ecotype samples taken from the local marketwere presented in Tables 1 and 2. For the majority of the almond nuts parameters such as weight, width, length, thickness, Dg, and volume, the statistical analyzes showed that the genotype L5 represents the highest values with the exception of sphericity, where the highest value was observed in the L6 genotype. Several forms have been observed for the different studies ecotypes round, ovate, oblong, and cordate (Table 1). The sizes ranged from medium to large, and all the hulls were hard during the crushing process. The weight of almond nuts varied between $3.2 \mathrm{~g}$ and $6.12 \mathrm{~g}$. The width, length, and thickness of the almond fruits ranged from $17.39 \mathrm{~mm}$ to $25.02 \mathrm{~mm}$, from 27.01 $\mathrm{mm}$ to $30.47 \mathrm{~mm}$ and from $14.71 \mathrm{~mm}$ to $19.25 \mathrm{~mm}$, respectively. The parameters calculated from the mathematical formulas, sphericity, and volume varied from $69.61 \%$ to $81.67 \%, 4086.07 \mathrm{~mm}^{3}$ to $7838.92 \mathrm{~mm}^{3}$ for almonds. While the yield and percentage of doubles varied from $22.37 \%$ to $34.21 \%$, from 6 to $100 \%$, and for the shape of the almond, four categories were found, intermediate, narrow, broad, and extremely broad (Table 2). Our results are comparable to those reported by Melhaoui et al. (2018) [7] on almond cultivars Marcona, Ferragnes, Ferraduel, and Fournat introduced in the same region. The studied almond genotypes show a great variability in morphological and pomological characters. Flowering was from early January to late March. This three-month interval justifies the great variability of the plant material. The yield for most almond ecotypes was low ranging from $22.37 \%$ to $34.21 \%$. It must be taken into account that these trees grow abundantly, without pruning, fertilizing or pesticide applications.

Table 1.Beldi almond nuts pomological characteristics.

\begin{tabular}{|c|c|c|c|c|c|c|c|c|c|c|c|}
\hline $\begin{array}{c}\text { Lo } \\
\text { t }\end{array}$ & $\begin{array}{c}\text { Weig } \\
\text { ht } \\
\text { (g) }\end{array}$ & $\begin{array}{c}\text { Widt } \\
\text { h } \\
(\mathbf{m m})\end{array}$ & $\begin{array}{c}\text { Leng } \\
\text { ht } \\
(\mathbf{m m})\end{array}$ & $\begin{array}{l}\text { Thickne } \\
\text { ss (mm) }\end{array}$ & Dg & $\begin{array}{c}\text { Spherici } \\
\text { ty }\end{array}$ & Volume & $\begin{array}{c}\text { Nut } \\
\text { shape }\end{array}$ & $\begin{array}{l}\text { Nut } \\
\text { size }\end{array}$ & Nut color & $\begin{array}{c}\text { Marking } \\
\text { of } \\
\text { outershel }\end{array}$ \\
\hline L1 & $3.20 \mathrm{a}$ & $19.74 a$ & $\begin{array}{c}29.84 \\
b c\end{array}$ & $15.00 \mathrm{a}$ & $\begin{array}{c}20.64 \mathrm{a} \\
\mathrm{b}\end{array}$ & $69.61 \mathrm{a}$ & $\begin{array}{c}4086.07 \\
\mathrm{a}\end{array}$ & $\begin{array}{c}\text { Oblon } \\
\mathrm{g}\end{array}$ & Large & $\begin{array}{c}\text { Intermedi } \\
\text { ate }\end{array}$ & $\begin{array}{c}\text { Sparsely } \\
\text { pored }\end{array}$ \\
\hline L2 & $\begin{array}{c}3.63 \mathrm{a} \\
\mathrm{b}\end{array}$ & $\begin{array}{c}17.39 \mathrm{a} \\
\mathrm{b}\end{array}$ & $\begin{array}{c}28.48 \\
\mathrm{~b}\end{array}$ & $15.21 \mathrm{a}$ & $19.78 \mathrm{a}$ & $69.77 \mathrm{a}$ & $\begin{array}{c}4741.25 \\
\mathrm{a}\end{array}$ & $\begin{array}{c}\text { Oblon } \\
\mathrm{g}\end{array}$ & $\begin{array}{c}\text { Mediu } \\
\mathrm{m}\end{array}$ & Light & $\begin{array}{l}\text { Intermedi } \\
\text { ate }\end{array}$ \\
\hline L3 & $\begin{array}{c}3.82 \mathrm{a} \\
\mathrm{b}\end{array}$ & $\begin{array}{c}20.55 a \\
b\end{array}$ & $27.01 \mathrm{a}$ & $16.14 \mathrm{~b}$ & $\begin{array}{c}20.74 \mathrm{a} \\
\mathrm{b}\end{array}$ & $77.74 \mathrm{bc}$ & $\begin{array}{c}5172.55 \\
\mathrm{a}\end{array}$ & $\begin{array}{c}\text { Corda } \\
\text { te }\end{array}$ & Large & Dark & $\begin{array}{c}\text { Densely } \\
\text { pored }\end{array}$ \\
\hline L4 & $\begin{array}{c}4.003 \\
\mathrm{~b}\end{array}$ & $\begin{array}{c}21.68 \\
\mathrm{~b}\end{array}$ & $\begin{array}{c}28.49 \\
\mathrm{~b}\end{array}$ & $14.71 \mathrm{ab}$ & $\begin{array}{c}20.85 a \\
b\end{array}$ & $73.22 \mathrm{ab}$ & $\begin{array}{c}5318.31 \\
\mathrm{a} \\
\end{array}$ & Ovate & Large & Dark & $\begin{array}{c}\text { Densely } \\
\text { pored }\end{array}$ \\
\hline L5 & $6.12 \mathrm{c}$ & $25.02 \mathrm{c}$ & $30.47 \mathrm{c}$ & $19.25 \mathrm{c}$ & $24.46 \mathrm{c}$ & $80.39 \mathrm{c}$ & $\begin{array}{c}7838.92 \\
b\end{array}$ & Round & Large & Light & $\begin{array}{c}\text { Sparsely } \\
\text { pored }\end{array}$ \\
\hline L6 & $3.94 \mathrm{~b}$ & $\begin{array}{c}22.24 \\
\text { bc }\end{array}$ & $27.37 \mathrm{a}$ & $18.35 \mathrm{c}$ & $\begin{array}{c}22.35 \\
b c\end{array}$ & $81.67 \mathrm{c}$ & $\begin{array}{c}5869.71 \\
a b\end{array}$ & Round & $\begin{array}{c}\text { Mediu } \\
\mathrm{m}\end{array}$ & Dark & $\begin{array}{c}\text { Sparsely } \\
\text { pored }\end{array}$ \\
\hline
\end{tabular}

Table 2. Beldi almond kernels pomological characteristics.

\begin{tabular}{|c|c|c|c|c|c|c|c|c|c|c|c|}
\hline $\begin{array}{c}\text { Lo } \\
\text { t }\end{array}$ & $\begin{array}{c}\text { Weigh } \\
\text { t } \\
(\mathrm{g})\end{array}$ & $\begin{array}{l}\text { Width } \\
\text { (mm) }\end{array}$ & $\begin{array}{c}\text { Leng } \\
\text { ht } \\
(\mathbf{m m})\end{array}$ & $\begin{array}{l}\text { Thickne } \\
\text { ss (mm) }\end{array}$ & Dg & $\begin{array}{c}\text { Spherici } \\
\text { ty }\end{array}$ & Volume & $\begin{array}{c}\text { Yield of } \\
\text { shelling } \\
\%\end{array}$ & $\begin{array}{c}\text { Doubl } \\
\text { e } \\
\text { kerne } \\
\text { ls } \\
0\end{array}$ & $\begin{array}{c}\text { Kernel } \\
\text { shape }\end{array}$ & $\begin{array}{c}\text { Kernel } \\
\text { colour } \\
\text { intensit } \\
\mathbf{y}\end{array}$ \\
\hline L1 & $\begin{array}{c}1.006 \mathrm{a} \\
\mathrm{b}\end{array}$ & $12.55 \mathrm{a}$ & $\begin{array}{c}23.26 \\
\mathrm{~b}\end{array}$ & $7.94 a$ & $\begin{array}{c}13.12 \\
\mathrm{a}\end{array}$ & $57.46 a$ & $\begin{array}{c}1190.22 \\
a b\end{array}$ & $34.21 \mathrm{~b}$ & 71 & $\begin{array}{c}\text { Intermedia } \\
\text { te }\end{array}$ & Dark \\
\hline L2 & $0.86 \mathrm{ab}$ & $\begin{array}{c}10.79 a \\
b\end{array}$ & $\begin{array}{c}21.34 \\
b\end{array}$ & $8.14 \mathrm{ab}$ & $\begin{array}{c}12.01 \\
\mathrm{a}\end{array}$ & $56.32 \mathrm{a}$ & $959.29 a$ & $24.82 \mathrm{a}$ & 22 & Narrow & Dark \\
\hline L3 & $0.75 \mathrm{a}$ & $\begin{array}{c}12.64 \mathrm{a} \\
\mathrm{b}\end{array}$ & $\begin{array}{c}17.52 \\
\mathrm{a}\end{array}$ & 7.79ab & $\begin{array}{c}11.98 \\
\mathrm{a}\end{array}$ & $68.62 \mathrm{~b}$ & $942.14 a$ & $24.33 a$ & 10 & $\begin{array}{c}\text { Extremely } \\
\text { Broad }\end{array}$ & Dark \\
\hline L4 & $0.86 \mathrm{ab}$ & $12.80 \mathrm{~b}$ & $\begin{array}{c}21.02 \\
b\end{array}$ & $6.77 \mathrm{~b}$ & $\begin{array}{c}12.15 \\
\mathrm{a}\end{array}$ & $58.32 \mathrm{a}$ & $990.52 a$ & $23.14 \mathrm{a}$ & 6 & Broad & Dark \\
\hline L5 & $1.16 \mathrm{~b}$ & $15.14 \mathrm{c}$ & 21.54 & $8.31 \mathrm{~b}$ & $\begin{array}{c}13.90 \\
\mathrm{a}\end{array}$ & $64.56 \mathrm{ab}$ & $\begin{array}{c}1429.12 \\
b\end{array}$ & $22.37 \mathrm{a}$ & 44 & $\begin{array}{c}\text { Extremely } \\
\text { Broad }\end{array}$ & Dark \\
\hline
\end{tabular}




\begin{tabular}{|l|l|l|l|l|l|l|l|l|l|l|l|}
\hline L6 & - & - & - & - & - & - & - & - & 100 & - & Dark \\
\hline
\end{tabular}

\subsection{Oil analyses of the four studied almond genotypes}

\subsubsection{Beldi almonds oils content}

This study shows significant differences in the analyzed almond oils content, ranging from 38.14 to $47.35 \%$, with L2 presenting the highest quantity of oils (Table 3). The obtained results show richness in oils of Beldi almond using screw press extraction comparable to the results obtained by using chemical extraction for other almond cultivars, were the oil content ranges from $35.27 \%$ to $40 \%$ [14], 40 to $65 \%$ [15], 48\% to 67\% [16], from $36.7 \%$ to $79 \%$ [17]. The obtained result shows, kernel rich in lipids, generally considered to be desirable for a healthy diet, or even preferable in the confectionery industry, because higher oil contents result in less water absorption by the almond paste, which makes local almond very appreciated in bakery and in the making of almond-based recipes [18].

\subsubsection{Acidity index}

The acidity indexis one of the most important parameters that define the quality of oils. The analysis of the studied almond oils showed a low content of free fatty acids which did not exceed $0.54 \%$ (Table 3 ). With an order grow according to the genotypes, L5 with $0.17 \%$, L4 and L1 with $0.19 \%$, and L 2 with $0.54 \%$. The results of the acidity index obtained are relatively low compared to those reported in the literature by M.M. Özcan et al. (2011)[19] for the Guara, Cristomorto, Tuono, Guara, Ferragnes, Nonpareil varieties, which are around 2,279\%, $3.55 \%, 1.38 \% 2.39 \% 1.89 \%$ respectively, and similar to those reported by Sakar et al., JMES, (2017)[20]. This index reflects the degree of degradation of the lipid reserves in the kernels in particular the triacyglycéroles. This degradation causes an increase in free fatty acids, the major fatty acid is oleicacid for the studied almond oils. During storage or extraction, the triacylglycerols can be degraded by endogenous or exogenous lipases brought about by microbial contamination. The low value of the acidity index obtained for the studied oils therefore shows a good quality of the oils produced in eastern Morocco.

\subsubsection{Peroxide index}

The peroxide index (PI) is a crude indicator of primary lipids amount of oxidation, it is a tool for measuring the amount of hydroperoxides formed by oxidation of fatty acids, especially polyunsaturated fatty acids. However, obtaining a low PI does not necessarily mean that the oil is not oxidized. Indeed in some cases, the kinetics of the oxidation of oils is very advanced and the hydroperoxides (dosed during the determination of the IP), are themselves transformed into secondary products some of which are volatile (the oil is then rancid). The peroxide index of the samples of almond oils studied varied between $6.82 \mathrm{meq} \mathrm{O} 2 / \mathrm{kg}$ and $13.25 \mathrm{meq} \mathrm{O} 2 / \mathrm{kg}$ (Table 3). The peroxide index of the L5, L4, and L1 genotypes is less than 8.89 meq O2 / kg, while the IP value of the oil extracted from the seeds of the L2 genotype was the highest $(13.25 \mathrm{meq} \mathrm{O} 2 / \mathrm{kg})$ compared to the other genotypes. The results of the peroxide index are relatively low compared to those reported in the literature by M.M. Özcan et al. (2011) [19]for other cultivars which varied between $7.58 \mathrm{meq} \mathrm{O} 2 / \mathrm{kg}$ and $15.59 \mathrm{meq} \mathrm{O} 2 / \mathrm{kg}$. The results of the IP obtained could signify a better quality of the oils extracted by pressure by KOMET Model DD85G compared to the Soxhlet process used by M.M. Özcan et al. (2011)[19] which has the disadvantage of being a hot chemical extraction process which promotes lipid peroxidation.

\subsubsection{Total polyphenol content}

The results of the total polyphenols analysis for the four studied almond oils were shown in Table3. The L5 genotype has the highest polyphenol content (437.85 mg.kg $\left.{ }^{-1}\right)$, followed by L4 (423.8 mg. $\left.\mathrm{kg}^{-1}\right)$, then with L1 and L2 $366.26 \mathrm{mg} \cdot \mathrm{kg}^{-1}$ and $353.58 \mathrm{mg} \cdot \mathrm{kg}^{-1}$, respectively. These values obtained were similar to those reported by Sakar et al. , JMES, (2017)[20]for other almond cultivars, while for other species phenols present lower values mainly for the most important fruit culture in eastern Morocco,which according to Mansouri et al., 2013 [21]virgin olive oil of autochthonous cultivars present only $316.59 \mathrm{mg} \cdot \mathrm{kg}^{-1}$. Polyphenols make a significant contribution to the quality of almonds. Almond polyphenols are primarily composed of tannins and flavonoids, which contribute to both nutrition value and health-promoting behavior according to Bolling, et al 2017 [22].Generally, greater phenolic content and relatively high antioxidant activity of cold-pressed nut oils eventually make them superior to those achieved by the solvent/soxhlet method[23]. 
Tables 3.Analysis of oil content, total phenolic content, acid index and peroxide index of Moroccan Beldi almonds.

\begin{tabular}{|c|c|c|c|c|}
\hline Lot & Oil content\% & Acid value (\% oleic acid) & Peroxide value (meq O2/kg) & Total phenolic contentmg/ Kg \\
\hline L1 & $40.27 \pm 0.2$ & $0.19 \mathrm{a} \pm 0.02$ & $8.89 \mathrm{a} \pm 0.02$ & $366.26 \mathrm{ab} \pm 0.3$ \\
\hline L2 & $47.35 \pm 0.01$ & $0.54 \mathrm{~b} \pm 0.02$ & $13.25 \mathrm{~b} \pm 0.04$ & $353.58 \mathrm{a} \pm 0.2$ \\
\hline L4 & $38.14 \pm 0.03$ & $0.19 \mathrm{a} \pm 0.02$ & $8.58 \mathrm{a} \pm 0.02$ & $413.58 \mathrm{ab} \pm 0.1$ \\
\hline L5 & $39.49 \pm 0.09$ & $0.17 \mathrm{a} \pm 0.002$ & $6.82 \mathrm{a} \pm 0.01$ & $437.85 \mathrm{~b} \pm 0.1$ \\
\hline
\end{tabular}

\subsection{Characterization of the Bledi almond cakes}

\subsubsection{Dry matter and moisture content of almond cakes.}

The dry matter of a sample corresponds to its mass after the complete evaporation of the free water. The results obtained from the oil cake samples (Table 4) have shown that there are significant differences between the varieties ( $\mathrm{p}<0.05$ ), with a content that varies between $92.03 \%$ for L5and $92.42 \%$ for L1.The variation of the dry matter implies the variation of the humidity rate. In fact, for the four genotypes, the humidity levels were on average of $7.58 \%$ for L1, 7.74\% for L5, 7.96\% for L2, and $8.59 \%$ for L4 (Data not shown). The values obtained are slightly lower than those for almond cake reported by M.M. Özcan et al. (2011)[19]. These results show that the oil cakes obtained from the kernels of the four studied genotypes were favorable for long-term conservation. In fact, on a microbiological level, low water contents limit the development of microorganisms, with the exception of molds [24]. The content of the dry matter is strongly influenced by the maturity stage of the seeds, the process of harvesting, and the storage conditions. Water content has a significant effect on the weight of the cake without affecting its nutritional value.[25].

\subsubsection{Ash content}

Ash represents the mineral part of almond cake and gives an idea of its contribution in mineral salts. Statistical analysis (ANOVA) of the total ash content revealed significant differences $(p<0.05)$ between the cakes of the different genotypes studied. The total ash contents were between $4.76 \%$ for L2 and $6.36 \%$ for L4. The values were higher than those reported by other studies concerning other varieties of almonds which have ash contents varying between $2.74 \%$ and $3.05 \%$ according to M.M. Özcan et al. (2011)[19].

\subsubsection{Total protein content}

Proteinsare the main constituent of muscle tissue, it's very important for growing or reproducing animals which they need a diet rich in protein for mass gain. The level of protein in a food is described as a percentage of total weight and often expressed as a percentage of crude protein. Statistical analysis of the results of the total protein content of the studied genotypes almond cakes $(\mathrm{p}<0.05)$, showed significant differences between the genotypes represented in table 4 by different letters (a-b).The almond cakeof L4 genotype has the highest content (44.61 $\%$ ), followed respectively by that of L1 $(36.84 \%)$, L2 $(36.67 \%)$, and L5(34.09\%)(Table 4). According to the results obtained, the significant differences could be explained by the genetic variability.Our results are comparable to those reported by Z. Ahmad (2010)[26].

\subsubsection{Crude cellulose content}

In this part of the study, we only analyzed one type of fibers, which is thecrude cellulose (Table 4).The results were presented in table 4 . The crude cellulose content varied between $9.67 \%$ (L5) and $21.75 \%$ (L2). However, too much fiber in the diet can reduce its nutritional value, resulting in stunted growth and reproductive performance and even death under conditions such as pregnancy toxemia [27]. 


\subsubsection{Total sugar composition}

Energy is obtained from carbohydrates, such as simple sugars, starch and fiber. These food components provide energy for animals to maintain body heat and to perform normal bodily functions and activities [27]. The total sugar content (Table4), expressed as a percentage of dry matter, varied between $16.73 \%$ for L5 and $17.42 \%$ for L1. These results are comparable to those reported by Houmy (2014)[28]. Statistical analysis of the results of the total sugars of almond cakes, showed that there are significant differences between the genotypes $(<0.05)$.

\subsubsection{Content of major mineral elements}

Statistical analysis (ANOVA) of the major mineral content of the oil cakes of the four almond genotypes studied shows significant differences $(\mathrm{p}<0.05)$. The results of the mineral macro-elements analysis in Beldi almond cakes have shown that potassium is the major element in this fraction in all the analyzed samples, followed by phosphorus then Magnesium, and Calcium (Figure 1). High potassium content was observed in L1 $\left(9.1 \mathrm{mg}^{-\mathrm{g}^{-1}}\right)$ while the lowest value was obtained withL4 $\left(6.08 \mathrm{mg} \cdot \mathrm{g}^{-1}\right)$. Potassium partially controls the metabolism of carbohydrates, promoting the synthesis of adenosinetriphosphoric acid and phosphocreatine as well as the release of pyruvic acid. It influences growth and participates in the activity of fundamental enzymatic systems such as that of carboxylases, peptidases [29]. Calciumand magnesium contents were between $3.05 \mathrm{mg}^{-\mathrm{g}^{-1}}$ for L2

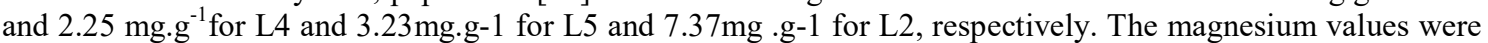
comparable to those reported by M.M. Özcan et al. (2011)[19]. Magnesium, like calcium, is involved in the process of neuromuscular excitability. In this sense, the deficiency in magnesium leads to hyperexcitability. While for the phosphorus contents it varied between $5.11 \mathrm{mg} . \mathrm{g}^{-1}$ (L5) and $7.07 \mathrm{mg}^{-\mathrm{g}^{-1}}$ (L1). These values are lower than those reported by other studies on almonds [19]. The L1 genotype is the richest in major mineral elements compared to the other studied genotypes and the L5 genotype showed the lowest values (Figure 1).Phosphorus is a component of deoxyribonucleic acid, which is basic for cell development and division. Similar to phospholipids, it contributes to the fluidity of the cell membrane; in the form of phosphate. It also helps preserve osmotic balance and plays a key role in several metabolic functions.

Table 4. Analysis ofdry matter, ash content, crude cellulose, and total sugars and protein of Beldi almonds cakes.

\begin{tabular}{|c|c|c|c|c|c|}
\hline Lot & Dry Matter \% & Ash\% & Crude Cellulose\% & Total Sugar\% & $\begin{array}{c}\text { Total Protein\% } \\
(\mathbf{N} \times \mathbf{6 , 2 5})\end{array}$ \\
\hline L1 & $92.42 \mathrm{~d} \pm 0.03$ & $5.52 \mathrm{~b} \pm 0.01$ & $10.03 \mathrm{a} \pm 0.3$ & $17.42 \mathrm{~b} \pm 0.3$ & $36.84 \mathrm{a} \pm 0.1$ \\
\hline L2 & $92.26 \mathrm{c} \pm 0.008$ & $4.76 \mathrm{a} \pm 0.04$ & $21.75 \mathrm{~b} \pm 0.3$ & $16.85 \mathrm{a} \pm 0.2$ & $36.67 \mathrm{a} \pm 0.2$ \\
\hline L4 & $92.40 \mathrm{a} \pm 0.03$ & $6.36 \mathrm{c} \pm 0.01$ & $11.76 \mathrm{ab} \pm 0.4$ & $16.74 \mathrm{a} \pm 0.4$ & $44.61 \mathrm{~b} \pm 0.4$ \\
\hline L5 & $92.03 \mathrm{~b} \pm 0.04$ & $5.31 \mathrm{~b} \pm 0.04$ & $9.67 \mathrm{a} \pm 0.5$ & $16.73 \mathrm{a} \pm 0.3$ & $34.09 \mathrm{a} \pm 0.2$ \\
\hline
\end{tabular}




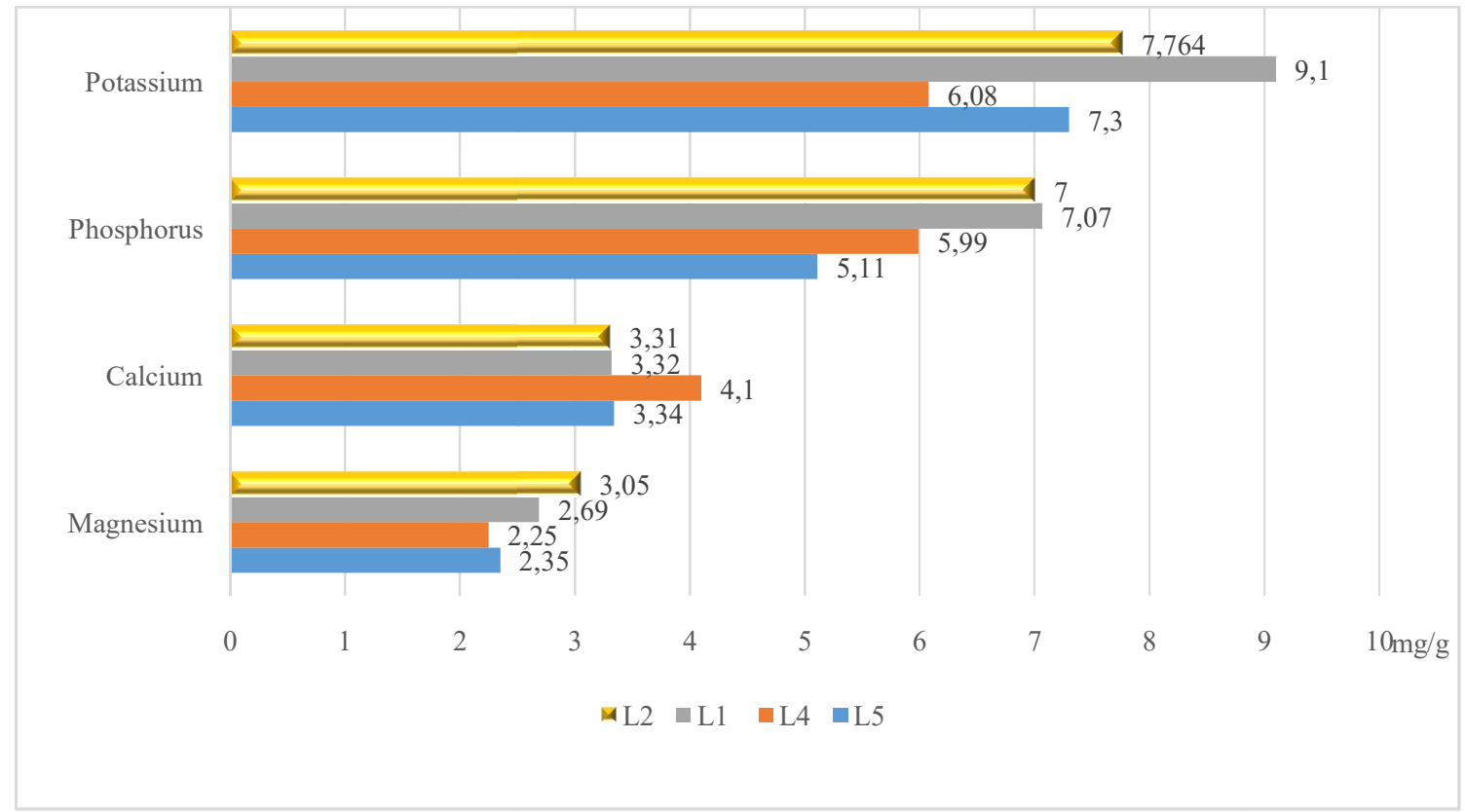

Fig. 1. Major mineral elements composition of Beldi almond cakes.

\subsection{Comparison between the Beldi ecotypes and Fg/Fdcultivars according to the major fatty acids and the tocopherol isomers grown in eastern Morocco}

Fatty acids and tocopherols are key nutrients that donate almonds different helpful capacities in numerous wellbeing viewpoints, in this manner, almond fatty acids and tocopherols are exceptionally critical for industry and researchers alike.

\subsubsection{Major fatty acids of Beldi almond and Fg/Fd produced in eastern Morocco}

Table 5 shows the relative proportions of the various fatty acid methyl esters (FAMEs) in the oils. Palmitic, oleic, linoleic, and the Stearic acid were the main FAMEs identified for both Beldi almond and Fg/Fd cultivars, with a dominance of Oleic acid. The highest value of saturated fatty acids was obtained with $\mathrm{Fg} / \mathrm{Fd}$ cultivarsand represents $11.22 \%$, while for Beldi almond it represents $10.39 \%$ of SFA, with the majority being palmitic acid 8.24 and $8.03 \%$ respectively. The content of monounsaturated (MUFA) fatty acids in the oils was higher for beldi Almond with $66.18 \%$, while $\mathrm{Fg} / \mathrm{Fd}$ it represents only $60.29 \%$. The unsaturated fatty acids were principally represented by oleic acid 65.27-58.96\%, followed bylinoleic acid $23.42-28.46 \%$ for Beldi and $\mathrm{Fg} / \mathrm{Fd}$ respectively. Similar results were reported by Mattha and Icp-aes (2020) [17].

\subsubsection{Composition of different tocopherol isomers of Beldi almond ecotypes and Fg/Fd cultivars grown in eastern Morocco}

Tocopherols presentedin table 6 show that the Moroccan Beldi almonds hold the highest total tocopherol contents with 499.37 mg.kg-1 of oil, compared to the introduced cultivars Fg/Fd with $425.03 \mathrm{mg} . \mathrm{kg}-1$ of oil. Similar results were obtained byMelhaoui, R (2018)[26] comparing to other cultivars grown in the same regions. Tocopherol analysis and the separation by HPLC revealed the presence of three tocopherol forms: $\alpha, \mathrm{B}$ and $\mathrm{V}$ with a dominance of $\alpha$-tocopherol for both Beldi almonds and $\mathrm{Fg} / \mathrm{Fd}$ cultivars, representing 97.6 and $98.13 \%$ of the total tocopherols content, respectively. The variability in the amounts of tocopherols obtained could beexplained by the environmental conditions and genotype effect[17].

Table 5. Major fatty acids of Beldi almond and Fg/Fdcultivars produced in eastern Morocco.

\begin{tabular}{|c|c|c|}
\hline Fatty acids & Fg/Fd & Beldi \\
\hline Palmitic acid C16:0 & $8.24 \mathrm{a}$ & $8.03 \mathrm{~b}$ \\
\hline Palmitoleic acid C16:1 & $1.24 \mathrm{~b}$ & $0.84 \mathrm{c}$ \\
\hline C17:0 & $0.03 \mathrm{a}$ & $0.04 \mathrm{a}$ \\
\hline
\end{tabular}




\begin{tabular}{|c|c|c|}
\hline C17:1 & $0.1 \mathrm{a}$ & $0.08 \mathrm{a}$ \\
\hline Stearic acid C18:0 & $2.93 \mathrm{c}$ & $2.32 \mathrm{~b}$ \\
\hline Oleic acid C18:1 & $58.95 \mathrm{c}$ & $65.26 \mathrm{~b}$ \\
\hline Linoleic acid C18:2n6 & $28.46 \mathrm{~b}$ & $23.42 \mathrm{a}$ \\
\hline SFA & 11.22 & 10.39 \\
\hline MUFA & 60.29 & 66.18 \\
\hline PUFA & 28.46 & 23.42 \\
\hline
\end{tabular}

Table 6.Oil content and composition of different tocopherol isomers of beldi almond ecotypes and $\mathrm{Fg} / \mathrm{Fd}$ cultivars produced in eastern Morocco.

\begin{tabular}{|c|c|c|}
\hline Tocopherols mg/kg & Fg/Fd & Beldi \\
\hline $\boldsymbol{\alpha}$-tocopherol & $425.03 \mathrm{a}$ & $499.37 \mathrm{a}$ \\
\hline $\boldsymbol{\beta}$-tocopherol & $2.28 \mathrm{c}$ & $2.82 \mathrm{c}$ \\
\hline Y-tocopherol & $5,80 \mathrm{~b}$ & $9.45 \mathrm{~b}$ \\
\hline $\boldsymbol{\delta}$-tocopherols & $\mathrm{ND}$ & $\mathrm{ND}$ \\
\hline Total tocopherols & 433.11 & 511,64 \\
\hline
\end{tabular}

\section{Conclusion}

Studies carried out on the quality of the fruit in these populations have revealed that the low commercial value it's explained by the small size of kernels, it wrinkled, its dark color and also by high percentages of double kernels. These negative traits reduce the marketable value of this ecotype because they do not meet the physical quality standards required by the market[16]. However, the chemical composition of these kernels has reached a very high quality suggesting other post-harvest potentials. These results are consistent with those obtained by[8].The multiple analyses showed that the studied almond cakes are potentially recoverable in the food industry. Indeed, it is an excellent source of fiber, protein, sugars, and minerals. For the studied genotypes, a considerable genetic diversity was observed in terms of phenological, pomological characters, and the physicochemical composition indicating that there is rich and precious plant material that makes these cakes potentially valuable in agro-foodand for the conservation of biodiversity.

\section{References}

1. A. Fernandez, I. Mart, C.F. i Forcada, K. Kamali, M. J. Rubio-Cabetas, M. Wirthensohn, R. S. i Company, GRCE, 205-219 (2015)

2. R. Kester, D.E. \& Asay, Almonds, Advances in Fruit Breeding, 387-419 (1975)

3. N. Richter-Dyn and N. S. Goel, Theor. Popul. Biol,3, 4, 406-433 (1972)

4. R. S. Company and A. J. Felipe, J. Hortic. Sci.,67, 3, 313-317 (2016)

5. [AOAC], Assn. of Of Analytical Chemists. Official methods of analysis (1990)

6. T. M. Gradziel, R. S.Company, Almonds Botany, Production and Uses (2017)

7. R. Melhaoui, M-L. Fauconnier, M. Sindic, M.Addi, M Abid, A Mihamou, H. Serghini-Caid, A. Elamrani , Int. J. Fruit Sci.,00, 00, 1-10 (2018)

8. O. Kodad, G. Estopañán, T. Juan, and R. Socias I Company, JAOCS, J. Am. Oil Chem. Soc, 90, 2, 243-252(2013)

9. A. Lansari, A. F. Iezzoni, and D. E. Kester, Euph.,78, 27-41, (1994)

10. D. Barile, J. D. Co1, M. Arlorio, M. Rinaldi, F.C.,17, 197-206 (2006)

11. R. Gülcan, Almond descriptors (revised),(1985)

12. E. E. Perez, G. H. Crapiste, and A. A. Carelli, Biosyst. Eng., 96, 1, 41-45 (2007)

13. A. H. Mirzabe, J. Khazaei, G. R. Chegini, and O. Gholami, Agric. Eng. Int. CIGR J., 15, 2, 256-265 (2013)

14. C. Aydin, J. F. Eng., 60 60, 315-320 (2003)

15. O. Kodad, R. S. Company, M. S. Prats, and M. C. L. Ortiz, HSB.,0316, (2016) 
16. S. I. COMPANY, J. Agric. Food Chem.,56, 4096-4101 (2008)

17. B. Mattha and G. Á. H. Á. Icp-aes, J F Sc Tech,(2020)

18. R. Socias i Company, O. Kodad, J. M. Alonso, and C. Font-Forcada, Séries A. Mediterr. Semin., 243, 94, 235-243 (2010)

19. D. A. Mehmet Musa Özcana, A. Ünvera, E. Erkanb, Sci. Hortic., 127, 330-333(2011)

20. E. H. Sakar, M. El Yamani, and Y. Rharrabti,JMES, 8, 8, 2679-2686 (2017)

21. F. Mansouri, A. Benmoumen, G. Richard, M.L. Fauconnier, M. Sindic3, H. Serghini-Caid, A. Elamrani, Riv. Ital. delle Sostanze Grasse, 93, 1, 21-30(2016)

22. B. W. Bolling, IFT., 00, 1-23 (2017)

23. K. Ghafoor, F. Al Juhaimi, and S. Hussain, JFST, (2018)

24. F. Chapeland-Leclerc, N. Papon, T. Noël, and J. Villard, Rev. Francoph. des Lab., 2005, 373, 6166(2005)

25. A.B. Siddique and D. Wright, AJPS., 2, 983-992 (2003)

26. Z. Ahmad, Ther. Clin. Pract., 16,1, 10-12(2010)

27. Hinton,Landlinks Press (2007)

28. N. Houmy, S. ElMoudden, M. Boujnah. orbi.uliege.be (2014)

29. L. Hennaux, L'alimentation minérale du bétail au Congo belge. l'Institut National pour l'Etude Agronomique du Congo Belge(1956) 